Sains Malaysiana 50(11)(2021): 3241-3250

http://doi.org/10.17576/jsm-2021-5011-08

\title{
Separation of Polar Compounds using Poly(Ethylene Oxide) Bonded Stationary Capillary Liquid Chromatography
}

(Pengasingan Sebatian Kutub menggunakan Kromatografi Cecair Kapilari Terikat Poli(Etilena Oksida))

\author{
Roza Linda*, Abdullah, Mohamad Rafi, Aster Rahayu, Lee Wah Lim \& Toyohide Takeuchi
}

\begin{abstract}
Poly(ethylene oxide) (PEO) bonded stationary phase has been synthesized by a single and simple step reaction. Poly(ethylene glycol monomethyl ether p-toluene sulfonate) (tosylated-PEO, molecular weight 900, $n \approx 18$ ) was chemically bonded to 3-aminopropyl silica (TSKgel $\mathrm{NH}_{2}-60,5 \mu \mathrm{m}$ particle size, and 60 A mean pore diameter). The prepared stationary phase was able to separate polar compounds such as phenolics and nucleobases in capillary liquid chromatography. The retention and separation of phenolics and nucleobases could be achieved under isocratic elution condition. Nucleobases such as thymine, adenine, uracil, uridine, cytidine and toluene and phenolics (phenol, pyrocatechol, pyrogallol) were baseline separated in less than 6 min using 98\% acetonitrile and less than 7 minutes using $80 \%$ acetonitrile, respectively. We demonstrated that the retention of nucleobases as analyte decreased with decreasing eluent concentration. The retention of these polar compounds was believed to be based on dipole-dipole and/or hydrogen-bonding interactions.
\end{abstract}

Keywords: Capillary liquid chromatography; poly(ethylene oxide); polar compounds

\section{ABSTRAK}

Fasa pegun terikat poli(etilena oksida) (PEO) telah disintesis melalui tindak balas langkah tunggal dan sederhana. Poli(etilena glikol monometil eter p-toluena sulfonat) (tosilated-PEO, berat molekul 900, $n \approx 18$ ) secara kimia terikat pada silika 3-aminopropil (TSKgel $\mathrm{NH}_{2}-60$, ukuran zarah 5 um dan diameter liang 60\%). Fasa pegun yang disediakan dapat memisahkan sebatian polar seperti fenol dan nukleobes dalam kromatografi cecair kapilari. Pengekalan dan pemisahan fenol dan nukleobes dapat dicapai dalam keadaan elusi isokratik. Nukleobes seperti timin, adenin, urasil, uridin, sitidin dan toluena serta fenol (fenol, pirokatekol, pirogalol) dipisahkan awal dalam masa kurang dari 6 minit menggunakan 98\% asetonitril dan kurang dari 7 minit masing-masing menggunakan 80\% asetonitril. Kami menunjukkan bahawa pengekalan nukleobes sebagai analit menurun dengan penurunan kepekatan eluen. Pengekalan sebatian kutub ini dipercayai berdasarkan interaksi ikatan dipol-dipol dan/atau hidrogen.

Kata kunci: Kromatografi cecair kapilari; polietilena oksida; sebatian kutub

\section{INTRODUCTION}

The stationary phase is the heart in the liquid chromatography, so it has gained much attention in search of excellent stationary phase with good separation of compound present in a sample. Silica-based are widely used as stationary phase in reversed phase-high performance liquid chromatography (RP-HPLC) system. Most of these stationary phases could be divided into two types with either modified $\mathrm{C}_{18}$ or novel molecules as functionalities (Guo et al. 2008). Although the silica-based ones have limited $\mathrm{pH}$ tolerance, they have some desirable features such as high efficiency and excellent mechanical stability, resistance to organic solvents, vigorous and stiff and fast mass transfer. Also, the rich silanol groups onto the surface of silica gel allow easy introduction of many functional groups onto the gel. Chromatographers have been developed various types of stationary phases for different purposes and the separation mode. Today many novel stationary phases for HPLC were synthesized to resolve some separation problems (Faria et al. 2006).

The variety and complexity of analytes in ionization and hydrophilicity are highly challenging and desirable 
for a single liquid chromatography (LC) analysis to separate polar compound with different level polarization. This separation needs stationary phases that can provide $\mathrm{RP}$, hydrophilic and/or ion exchange interactions simultaneously. Recently, mixed-mode stationary phases with more than one retention mechanism and the capability to be operated in different LC modes have been reported (Wang et al. 2016a; Wei et al. 2016). The Scherzo stationary phase by Imtakt (2020) is constructed by mixing two types of bonded silica particles, one modified with $\mathrm{C}_{18}$ and cation exchange functionalities, and the other one with $\mathrm{C}_{18}$ and anion exchange functionalities. These columns are positioned as general-purpose columns for a broad range of LC applications. Wang et al. (2016b) have developed a reversed-phase/zwitterionic/hydrophilic interaction liquid chromatography stationary phase, named as SIL-PS for the separation selectivity, the non-steroidal anti-inflammatory drugs, nucleobases/nucleotides, and alkaloids/glycosides. Dier et al. (2017) have synthesized novel phosphonium-based ionic liquid stationary phases and applied for the separation of complex mixtures of decomposed lignin.

Poly(ethylene glycol) (PEG) is a polyether compound and has been known for many applications, one of them is for the stationary phase in gas chromatography and liquid chromatography. PEG is one of example neutral stationary phase because this stationary phase does not have charged or chargeable groups (Zhang et al. 2015). In recent years, a novel RP-HPLC stationary phase with PEG as functionality was introduced and attracted increasing attention. Guo et al. (2008) have been reported separation of phenyl compounds in Traditional Chinese Medicine using PEG as the stationary phase. Separation of some phenolic acid and flavones with PEG as the stationary phase also has been investigated by Jandera and Hajek (2009). PEG could resolve the separation of polar compounds because could provide dipole-dipole and hydrogen interaction, so perhaps polar compound could be retained longer in the PEG stationary phase. A helix-like conformation in the organic aqueous media is the other PEG properties that PEG could form different selectivity compared to common $\mathrm{C}_{18}$ stationary phase (Takeuchi et al. 2009).

In the previous work, we have made and evaluated the PEO-bonded stationary phase for the separation of six inorganic anions in capillary ion chromatography. We have used tosylated-polyethylene oxide to synthesize the PEO-bonded stationary phase (Linda et al. 2013). To have a broader application and check the possibility of other mode like hydrophilic interaction for this stationary phase, we used the PEO-bonded stationary phase with tosylated-polyethylene oxide as the PEGylation reagent for the separation of some polar compound such as nucleobases (thymine, adenine, uracil, uridine, and cytidine), toluene and some phenolics (phenol, pyrocatechol, pyrogallol). In this study, we also used a capillary liquid chromatography system for the separation of the analytes because eco-friendly waste (less solvent use for mobile phase), small injected sample volume and improved mass sensitivity (Lim 2015).

\section{Materials AND Methods}

\section{MATERIALS}

Poly(ethylene glycol monomethyl ether p-toluenesulfonate) (tosylated-PEO, molecular weight $900, \mathrm{n} \approx 18$ ) was purchased from Sigma-Aldrich ( $\mathrm{St}$ Louis, USA) and 3-aminopropylsilica (TSKgel $\mathrm{NH}_{2}-60.5$ $\mu \mathrm{m}$ particle diameter, $60 \AA$ mean pore diameter) were obtained from (TOSOH, Tokyo, Japan). Acetonitrile, methanol, phosphate buffer ( $\mathrm{pH}$ 6-8), thiamine, adenine, uracil, uridine, cytidine, phenol, and pyrogallol, silica capillary column $(0.32 \mathrm{~mm}$ id), PTFE capillary tube $(0.52$ $\mathrm{mm}$ id) and membrane filter $(0.45 \mu \mathrm{m})$, were obtained from Wako Pure Chemical Industries (Osaka, Japan). Pyrocatechol and toluene were purchased from Nacalai Tesque (Kyoto, Japan).

\section{APPARATUS}

The chromatographic measurements were carried out by using a $\mu \mathrm{LC}$ system. The system consists of a pump L.TEX-8301 Micro Feeder (L. TEX Corporation, Japan) to supply the mobile phase, which is equipped with a syringe $(0.5 \mathrm{~mL}$ syringe), an injector M435 micro injection valve (Upchurch Scientific, Oak Harbor, WA, USA) with an injection volume of $0.2 \mu \mathrm{L}$, and a UV-970 UV-Vis detector (Jasco, Tokyo, Japan) was operated at 254 $\mathrm{nm}$. CDS data processor (LASOFT, Chiba, Japan) used as the data collector. The synthesized packing material was evaluated for its elemental composition using MT-6 CHN Corder (Yanaco, Kyoto, Japan).

\section{PREPARATION AND PACKING OF PEO-BONDED STATIONARY PHASE}

Preparation of the PEO-bonded stationary phase has followed the procedure developed by Linda et al. (2013) with slight modification. In this work, we used tosylated- 
PEO with molecular weight about 900 and $\mathrm{n} \approx 18$. About $0.35 \mathrm{~g}$ of tosylated-PEO and $0.21 \mathrm{~g}$ of TSKgel $\mathrm{NH}_{22}-60$ were added into $5 \mathrm{~mL}$ of acetonitrile in a $20 \mathrm{~mL}$ vial, and then the solution was poured into the stainless steel column. The reaction was taken place in oven at $75^{\circ} \mathrm{C}$ for $24 \mathrm{~h}$, followed by washing with methanol. The reaction product (PEO-bonded silica) was packed in a silica capillary column $(0.32 \mathrm{~mm}$ id $\times 100 \mathrm{~mm})$ using a slurry method as reported by Takeuchi and Ishii (1981). Before used as the stationary phase, the column was washed with phosphate buffer ( $\mathrm{pH}$ 7.5) for about $1 \mathrm{~h}$.

\section{RESULTS AND DISCUSSION}

The 3-aminopropyl silica and the PEO-bonded stationary phase were characterized by elemental analysis. The increase of the carbon and hydrogen content for the latter demonstrated that PEO was bonded to 3 -aminopropyl silica successfully. The percentages by weight of the 3 -aminopropyl silica were $4.13 \%$ and $1.54 \%$ for carbon and hydrogen, respectively. We found carbon and hydrogen contained in the PEO-bonded stationary phase were about 9.34 and $2.00 \%$, respectively. In other words, $11 \%$ of amino groups of the 3-aminopropyl silica were bonded with PEO. SEM photos (Figure 1) of the PEO-bonded stationary phase showed the morphology of aminopropyl silica reacted with tosylated-PEO. The estimation range diameter of the synthesized material was $1.5-2.7 \mu \mathrm{m}$.

Figure 2 shows that in primary amines (3-aminopropylsilica), there are more nucleophilic free electron pairs that will attack carbon atoms in electrophilic polyethylene oxide, so that there will be a breakdown of carbon and oxygen bonds in the polyethylene oxide group and the p-toluene sulfonate ion. The amine group that binds to carbon polyethylene oxide will be positively charged, while the p-toluene sulphonate ion group which is negatively charged. It will take hydrogen atoms in the amine group, so that the desired product formed is compound 3 PEOmodified aminopropylsilica and p-toluene sulfonic acid by products. The resulting product is expected to be able to hold polar compounds, especially flavonoids in the column, so that the separation of flavonoids can run well and efficiently. This reaction mechanism is in accordance with the reaction scheme that has been reported by Linda et al. (2013).
FTIR spectrum of the 3-aminopropyl silica stationary phase before and after modification with PEO (Figure 3 ) showed the absorption bands at the wavenumber of $790.81 \mathrm{~cm}^{-1}$ and $968.27 \mathrm{~cm}^{-1}$ which are the vibrations of stretching Si-O on silanol. Absorption at $470.20 \mathrm{~cm}^{-1}$ showed the presence of siloxane bending vibrations. The existence of $\mathrm{Si}-\mathrm{O}$ functional groups was characterized by the absorption in the $1010-110 \mathrm{~cm}^{-1}, 800 \mathrm{~cm}^{-1}$, and 460 $\mathrm{cm}^{-1}$ (Guo et al. 2013; Javadian et al. 2017). Absorption at $1089 \mathrm{~cm}^{-1}$ showed the asymmetric stretching vibration of $\mathrm{Si}-\mathrm{O}$ in siloxane. In general, the absorption appears on the spectrum showed that the functional groups in silica are silanol or $\mathrm{Si}-\mathrm{OH}$ and siloxane or $\mathrm{Si}-\mathrm{O}-\mathrm{Si}$.

The FTIR spectrum of the stationary silica and PEO modified silica phases showed the same pattern and only differ in the intensity and shape of the peaks resulting from the silica group. In addition, the resulting spectrum also did not show any absorption bands from $\mathrm{N}-\mathrm{H}, \mathrm{C}-\mathrm{N}$ groups, and absorption by the presence of PEO groups. Based on previous paper reported (Jodeh et al. 2016; Radi et al. 2011; Sun et al. 2013), the absorption band for N-H bonds appears at wave number $1590 \mathrm{~cm}^{-1}$, while the absorption band in the $1338 \mathrm{~cm}^{-1}$ indicates the vibration stretching of $\mathrm{C}-\mathrm{N}$. In addition, several bands of moderate intensity in the region 2872-2929 and 1467 $\mathrm{cm}^{-1}$ are associated with $\mathrm{C}-\mathrm{H}$ stretching of the propyl group and N-H stretching modes (Yusmaniar et al. 2018; Zhang et al. 2008).

According to Polu and Kumar (2011), the PEO group from the PEO modified silica stationary phase was shown by the emergence of new absorption bands in the absorption area of $3378 \mathrm{~cm}^{-1}$. The peak indicates an $\mathrm{OH}$ stretching vibration that indicates hydrogen bonds. Polu and Kumar (2011) also explained that the difference in the stationary phase IR spectrum after modification was seen at the absorption peak of the $2803 \mathrm{~cm}^{-1}$ region which showed the stretching of the methylene group found in PEO. This confirms that the polymerization reaction on silica has been successfully formed. However, from the FTIR spectrum resulting from this study, no PEO group, amine group, and C-N group were detected. This happens because the intensity of the transmittance produced is too low, so as if undetected. To prove the existence of amine and methylene groups from the formed PEO can be seen in elemental analysis. 

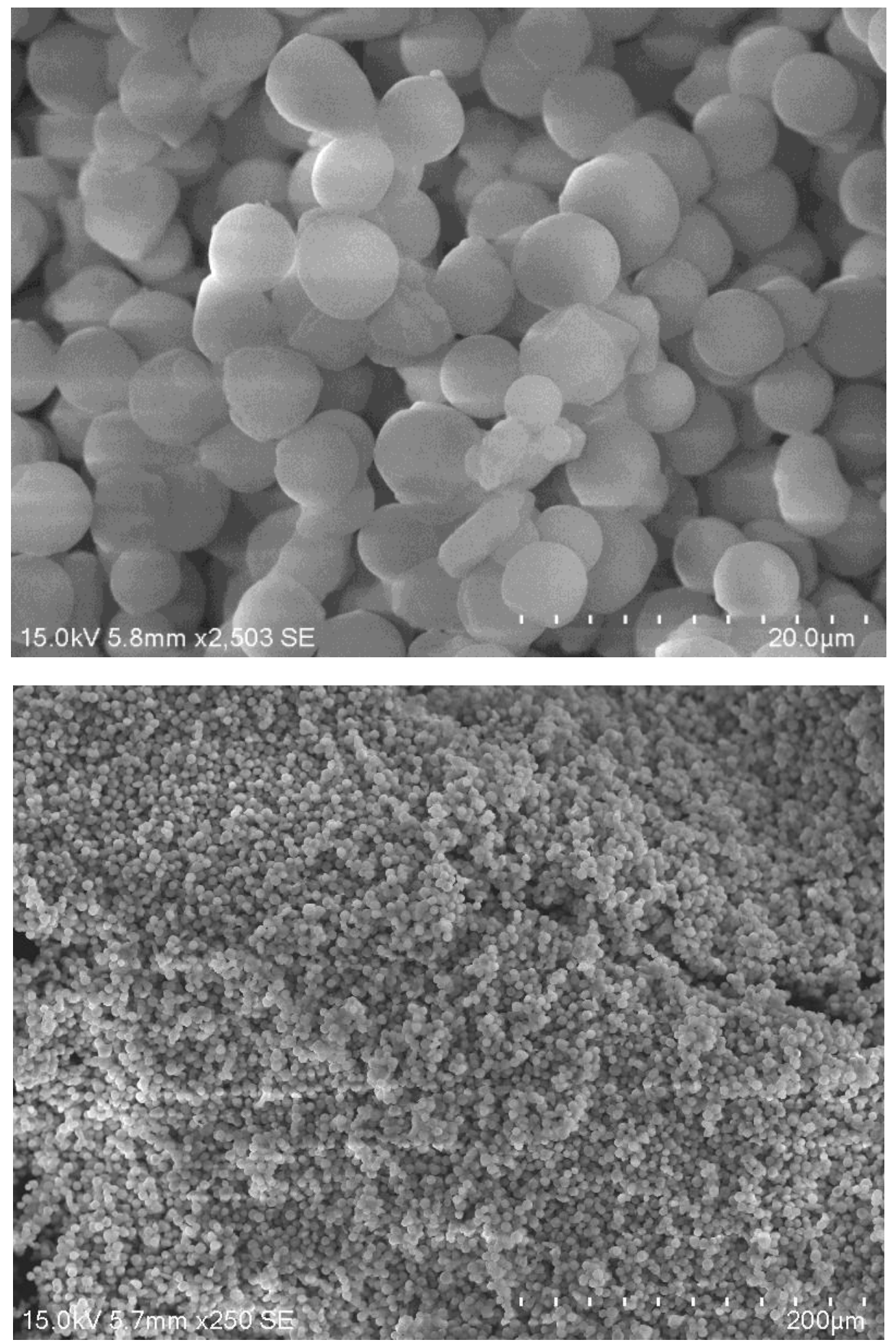

FIGURE 1. SEM photo of PEO bonded stationary phase 


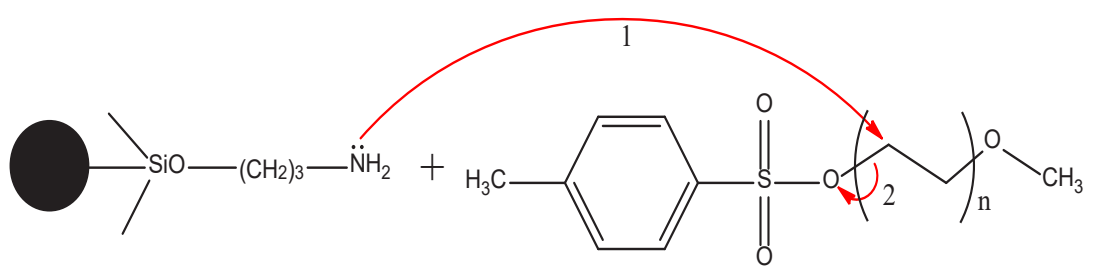

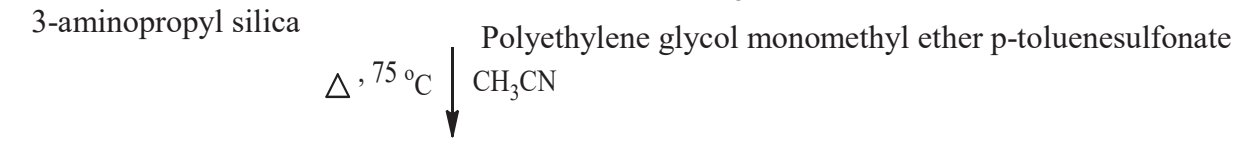

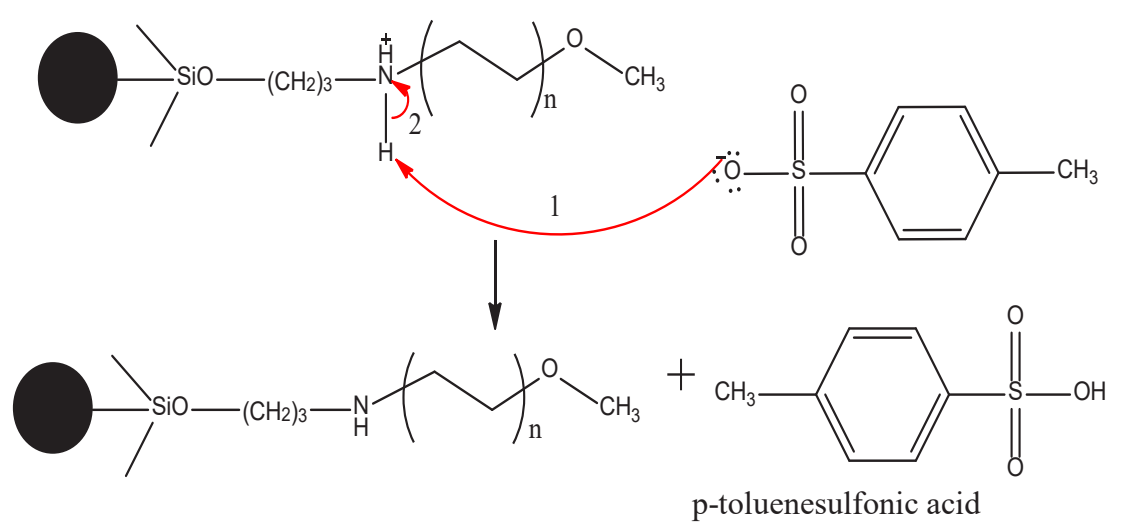

FIGURE 2. Mechanism of reaction for making PEO modified silica phases

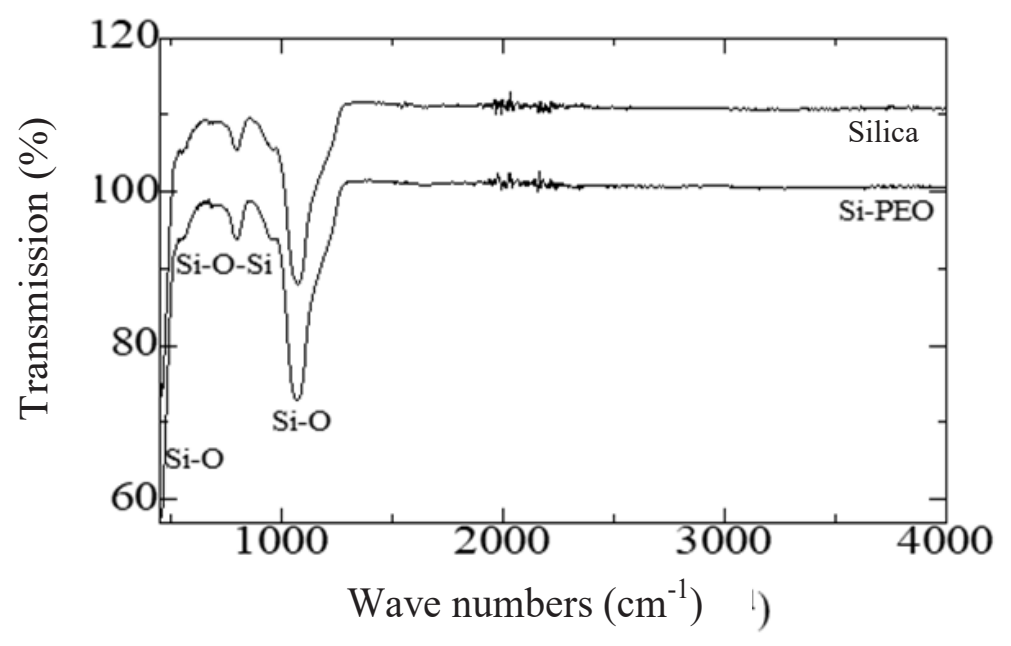

FIGURE 3. FTIR spectrum of a) silica and b) PEO modified silica 


\section{SEPARATION OF NUCLEOBASES}

The PEO-bonded stationary phase possesses oxygen atoms at multiple PEO chains, so it is expected to show separation ability towards polar compounds due to the specific interactions such as dipole-dipole or hydrogen bonding interactions. The prepared PEO bonded stationary phase was evaluated for the separation of polar compounds such as nucleobases and phenolics. The effect of type, concentration and flow rate of mobile phase was investigated in this work.

Satisfactory resolution shown by PEO bonded stationary phase in the separation of nucleobases (thymine, adenine, uracil, uridine, cytidine) and toluene. Separation of those compounds forming RNA/DNA can be performed in isocratic elution conditions, using acetonitrile as the mobile phase as shown in Figure 4. The figure demonstrates the applicability of the PEO bonded column as it typically retains and resolves those compounds quite well. The concentration of the mobile phase affects the resolution of the separation. The resolution was increased with the increasing of acetonitrile concentration as the mobile phase with $98 \%$ acetonitrile gives the best separation results.

The concentration of the mobile phase affects the resolution of the analytes. Since acetonitrile gave the best resolution for all nucleobases used in this study, we compared four acetonitrile composition as the eluent. We used concentration of acetonitrile as the mobile phase in the range of $20-80 \%$. From the chromatogram obtained (Figure 5) for the separation of the analytes showed the resolution of each analytes increases with the increasing of acetonitrile concentration as the mobile phase. We found $80 \%$ acetonitrile gives excellent separation results.

The flow rate of the mobile phase showed an influence in the capabilities of the stationary to retain the analytes with a good resolution. We evaluated the flow rate of the mobile phase for their influence by using $1,2,3$, and $4 \mu \mathrm{L} / \mathrm{min}$. From Figure 6 , we can see that higher flow rate would make the separation faster, but the resolution was not good. The flow rate of $2 \mu \mathrm{L} / \mathrm{min}$ is an option that can accommodate between separation and reasonable resolution of the sample.

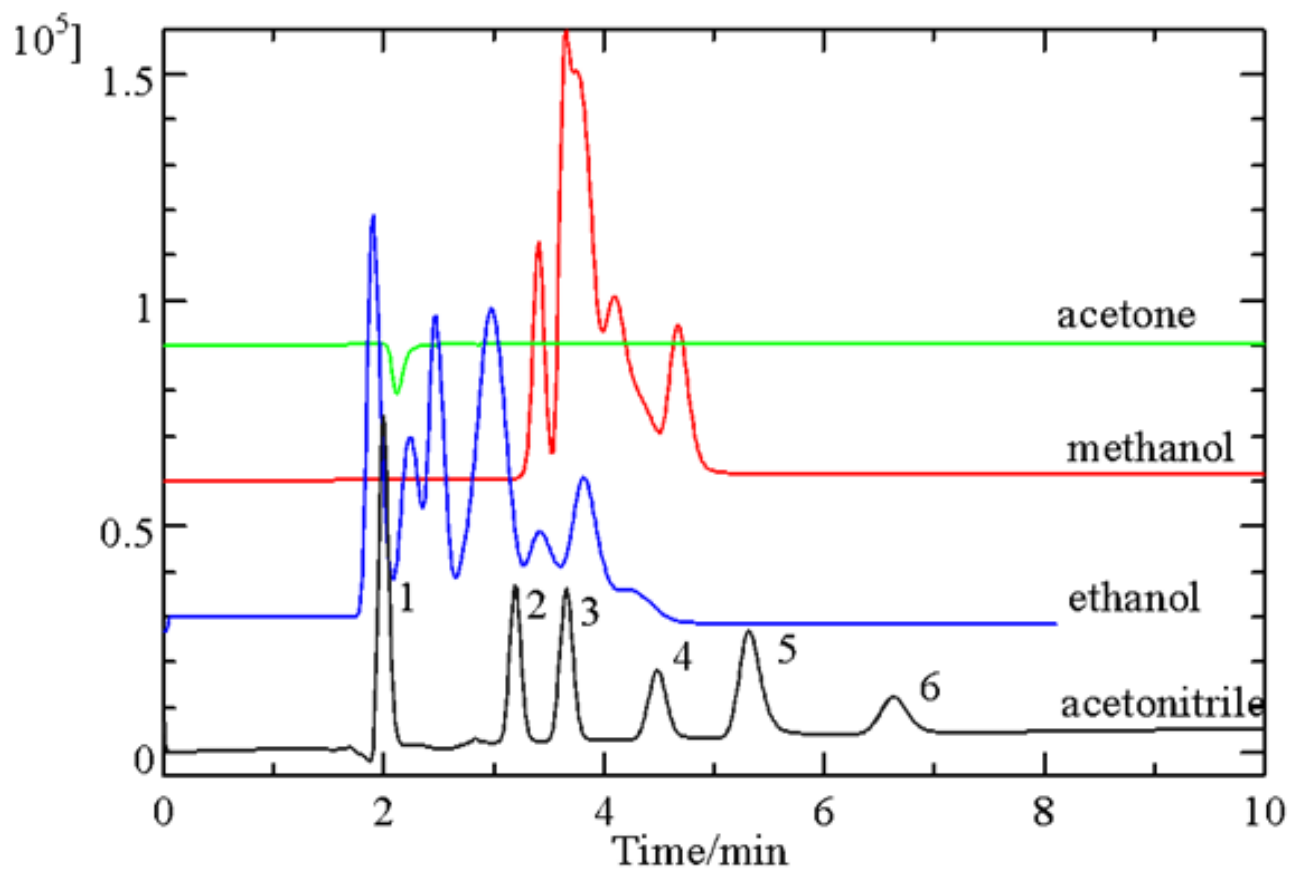

FIGURE 4. Effect of various eluent on separation of six nucleobases. Operation condition: PEO bonded column, Analytes, $0.01 \mathrm{~g} \mathrm{l}^{-1}$ of each toluene (1), thymine (2), adenine (3), uracil (4), uridine (5), cytidine (6); $0.2 \mu \mathrm{L}$ injection volume; UV detection $254 \mathrm{~nm}$ : flowrate $3 \mu \mathrm{L} \mathrm{min}{ }^{-1}$ 


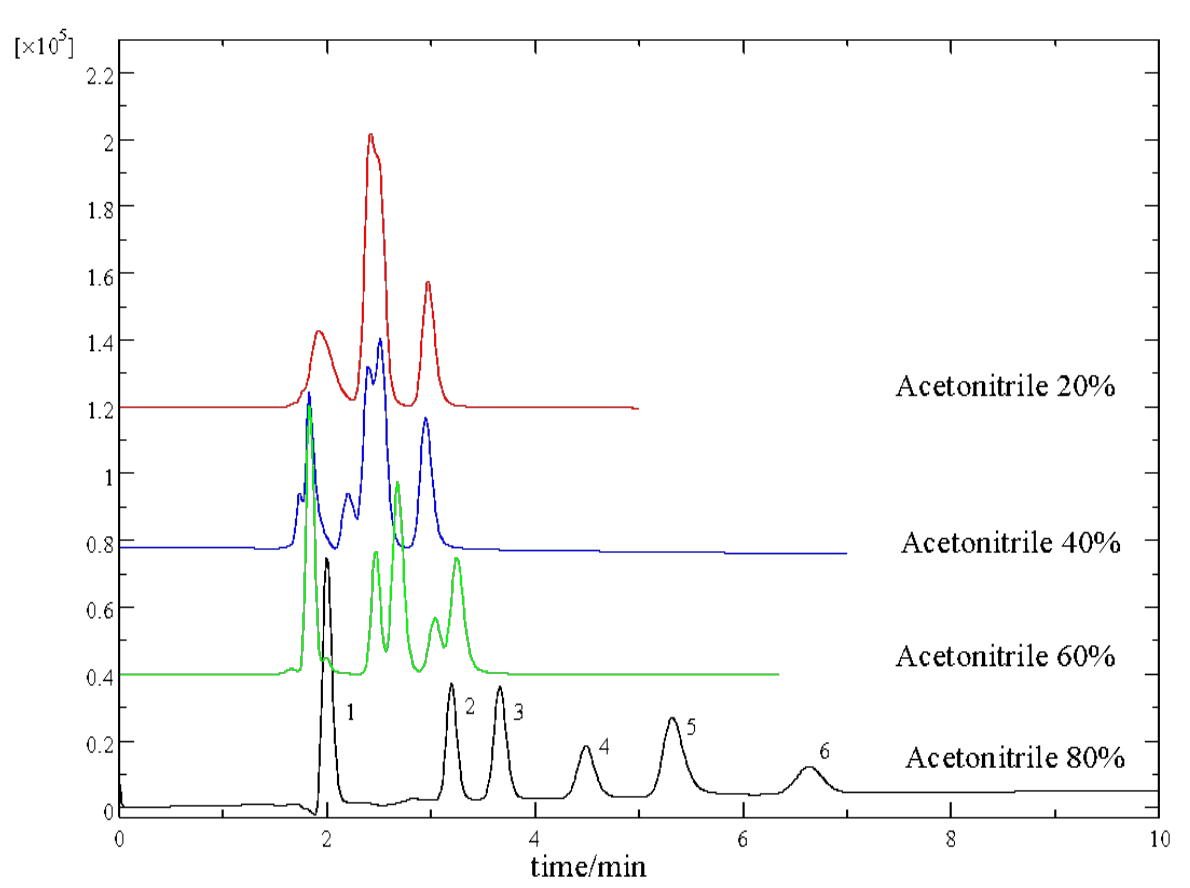

FIGURE 5. Effect of acetonitrile concentration on separation of nucleobases Operating conditions as in Figure 4

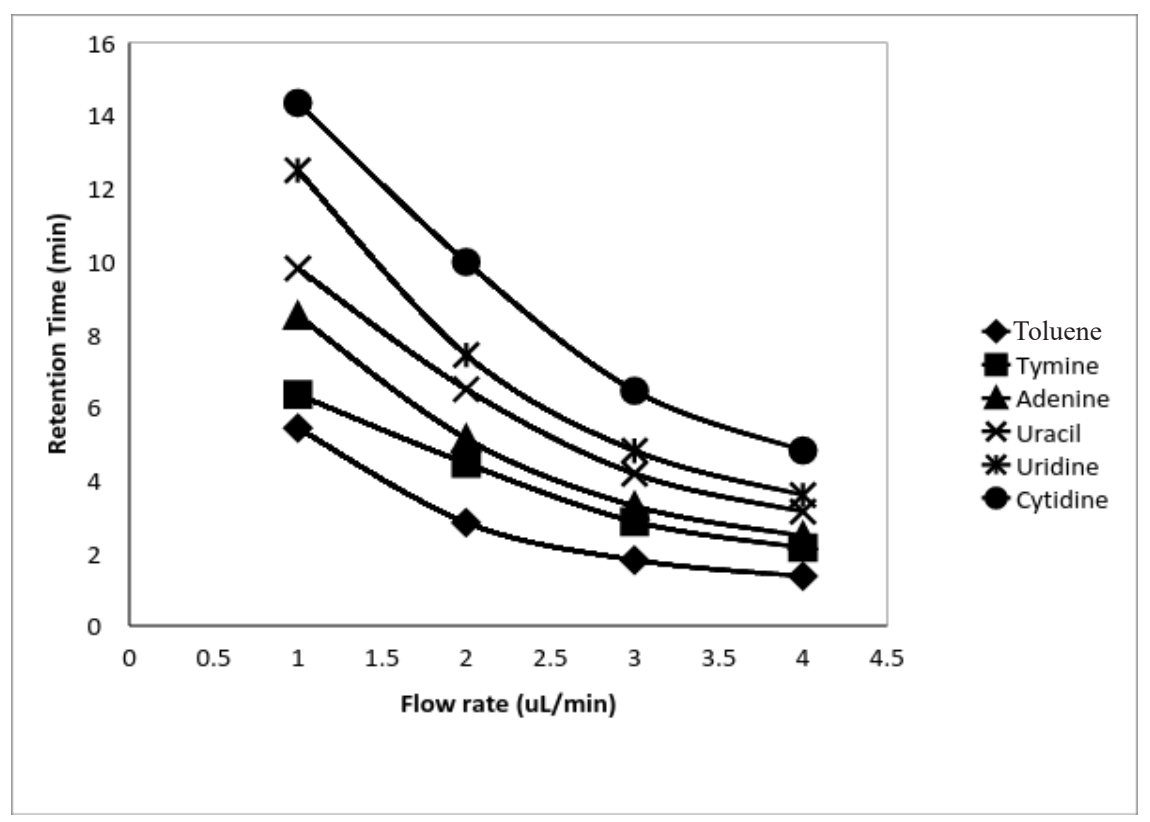

FIGURE 6. The retention time of analyte nucleobases as a function eluent flowrate; on PEO bonded stationary phase. Operating conditions as in Figure 2 except for the eluent flowrate 


\section{SEPARATION OF PHENOLICS}

The stationary phase of PEO bonded to silica was also evaluated in the separation of some phenolics compound such as phenol, pyrocatechol, and pyrogallol which is one of the pollutants in the water and wastewater systems. Separation of this phenolic compounds using isocratic elution conditions with acetonitrile as the mobile phase and UV as the detector. Figure 7 showed the chromatogram obtained for the separation of three phenolics analytes. The separation was completed less than 6 min with pyrocatechol eluted first followed by phenol and pyrogallol.

Sequence compound separation results show not only based on the elucidation of the polarity. Phenol has one $\mathrm{OH}$ group in its structure, as theoretical has a polarity lower than pyrocatechol (2 OH group) and pyrogallol (3 OH groups). This result indicating that the separation of phenolic compounds by PEO bonded stationary phase is not only influenced by the polarity via dipole-dipole interactions or hydrogen bonding interactions. It needs the further investigation to determine the mechanism of separation of phenolic compounds by PEO bonded stationary phase. In this study, also found that the concentration of the mobile phase influences the separation profile, especially the resolution of the separation. Increasing concentrations of acetonitrile were used as mobile phase, causing increased separation resolution. We found that $98 \%$ acetonitrile gives the best separation results.

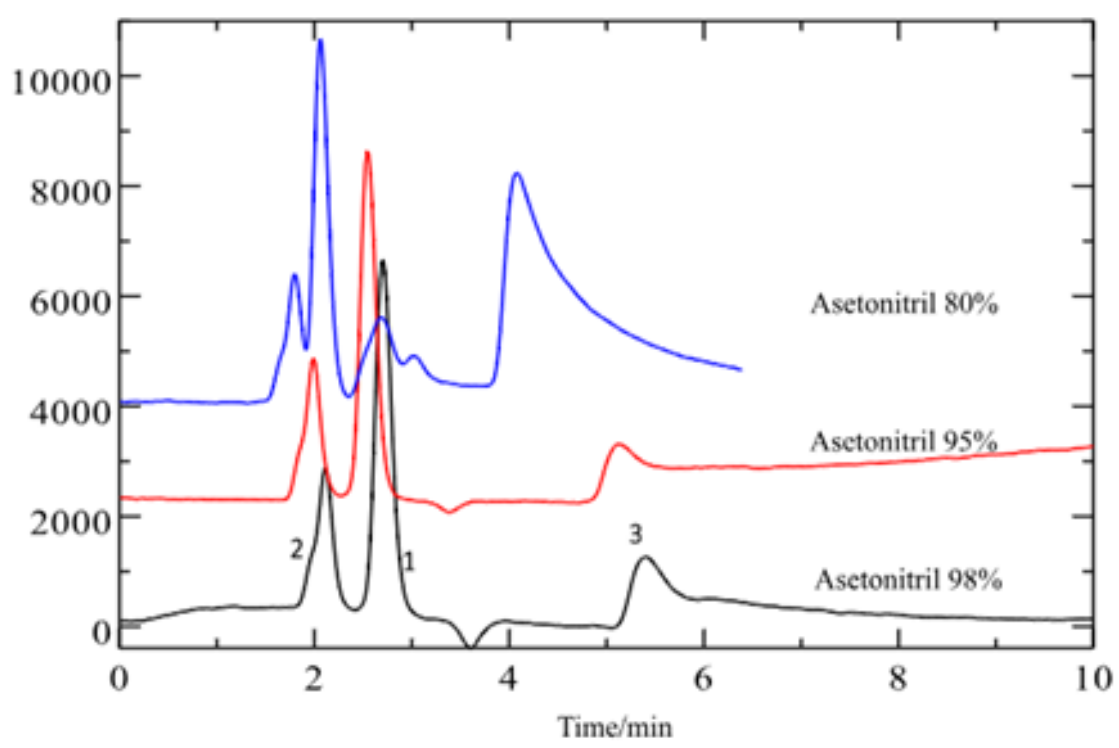

FIGURE 7. Effect of various concentration of acetonitrile as eluent for separation of phenols. Operation condition: PEO bonded column, Analytes, $0.01 \%$ of each phenol (1), pyrocatechol (2), pyrogallol (3); $0.2 \mu \mathrm{L}$ injection volume; UV detection $254 \mathrm{~nm}$ : flowrate $3 \mu \mathrm{L} \mathrm{min}^{-1}$

\section{CONCLUSION}

A simple and single step reaction of PEO-bonded silica stationary phase has been prepared for the separation of nucleobases and phenolics in capillary liquid chromatography. Thymine, adenine, uracil, uridine, cytidine and toluene could be separated less than $6 \mathrm{~min}$ using 98\% acetonitrile while phenol, pyrocatechol, and pyrogallol were separated less than 7 min with $80 \%$ acetonitrile. The chromatographic results showed that PEO bonded silica can be an acceptable alternative for the rapid analysis of nucleobases and phenolics.

\section{ACKNOWLEDGEMENTS}

This work was supported by the Penelitian Kerjasama Luar Negeri Research Grant 2018 (No: 1585/IT3.11/ PN/2018) and partly support by Penelitian Fundamental 
Research Grant 2015 from the Directorate of Research and Community Services, Ministry of Research, Technology and Higher Education, Republic of Indonesia.

\section{REFERENCES}

Dier, T.K.F., Rauber, D., Jauch, J., Hempelmann, R. \& Volmer, D.A. 2017. Novel mixed-mode stationary phases for chromatographic separation of complex mixtures of decomposed lignin. Chemistry Select 2: 779-786.

Faria, A.M., Collins, K.E. \& Collins, C.H. 2006. New stationary phases for high-performance liquid chromatography based on poly(methyltetradecylsiloxane) thermally immobilized onto zirconized silica. Journal of Chromatography A 1122: 114-122.

Guo, Z., Liu, Y., Xu, J., Xu, Q., Xue, X., Zhang, F., Ke, Y., Liang, X. \& Lei, A. 2008. Novel reversed-phase high-performance liquid chromatography stationary phase with oligo(ethylene glycol) "click" to silica. Journal of Chromatography A 1191: 78-82.

Guo, W., Chen, R., Liu, Y., Meng, M., Meng, X., Hu, Z. \& Song, Z. 2013. Preparation of ion-imprinted mesoporous silica SBA15 functionalized with triglycine for selective adsorption of Co(II). Colloids and Surfaces A: Physicochemical and Engineering Aspects 436: 693-703.

Imtakt. 2020. Scherzo SM-C18. https://www.imtaktusa.com/ product/scherzo-sm-c18/. Accessed on March 2020.

Jandera, P. \& Hajek, T. 2009. Utilization of dual retention mechanism on columns with bonded PEG and diol stationary phases for adjusting the separation selectivity of phenolic and flavone natural antioxidants. Journal of Separation Science 32: 3603-3619.

Javadian, H., Koutenaei, B.B., Khatti, R. \& Toosi, M. 2017. Application of functionalized nano HMS type mesoporous silica with $\mathrm{N}$-(2-aminoethyl)-3-aminopropyl methyldimethoxysilane as a suitable adsorbent for removal of $\mathrm{Pb}$ (II) from aqoeous media and industrial wastewater. Journal of Saudi Chemical Society 21: 219-230.

Jodeh, S., Amarah, J., Radi, S., Hamed, O., Warad, I., Salghi, R., Chetouni, A., Samhan, S. \& Alkowni, R. 2016. Removal of methylene blue from industrial wastewater in Palestine usingpolysiloxane surface modified with bipyrazolic tripodal receptor. Moroccan Journal of Chemistry 4: 140-156.

Lim, L.W. 2015. Development of micro-flow-controlled techniques and novel stationary phases in capillary liquid chromatography. Chromatography 36: 1-12.

Linda, R., Lim, L.W. \& Takeuchi, T. 2013. Poly(ethylene oxide)bonded stationary phase for separation of inorganic anions in capillary ion chromatography. Journal of Chromatography A 1294: 117-121.

Polu, A.R. \& Kumar, R. 2011. Impedance spectroscopy and ftir studies of PEG-based polymer electrolytes. E-Journal of Chemistry 8: 347-353.

Radi, S., Tighadouini, S., Toubi, Y. \& Bacquet, M. 2011. Polysiloxane surface modified with bipyrazolic tripodal receptor for quantitative lead adsorption. Journal of Hazardous Materials 185: 494-501.

Sun, M., Feng, J., Luo, L., Liu, X. \& Jiang, S. 2013. Benzimidazole modified silica as a novel reversed-phase and anionexchangemixed-mode stationary phase for HPLC. Talanta 105: 135-141.

Takeuchi, T. \& Ishii, D. 1981. High-performance micro packed flexible columns in liquid chromatography. Journal of Chromatography A 213: 25-32.

Takeuchi, T., Oktavia, B. \& Lim, L.W. 2009. Poly(ethylene oxide)bonded stationary phase for capillary ion chromatography. Analytical and Bioanalytical Chemistry 393: 1267-1272.

Wang, L., Wei, W., Xia, Z., Jie, X. \& Xia, Z.Z. 2016a. Recent advances in materials for stationary phases of mixedmode high-performance liquid chromatography. Trends in Analytical Chemistry 80: 495-506.

Wang, Q., Xu, L. \& Xue, Y.W. 2016b. Preparation, evaluation, and application of a novel reversed-phase/zwitterionic/ hydrophilic interaction liquid chromatographic mixed-mode stationary phase. Journal of Liquid Chromatography \& Related Technologies 39: 598-606.

Wei, Z., Fu, Q., Cai, J., Huan, L., Zhao, J., Shi, H., Jin, Y. \& Liang, X. 2016. Evaluation and application of a mixed-mode chromatographic stationary phase in two-dimensional liquid chromatography for the separation of traditional Chinese medicine. Journal of Separation Science 39: 22212228.

Yusmaniar, Y., Darwis, D., Afrizal, A. \& Annisa, A. 2018. Synthesis of silica of rice husk modification (3-aminopropyl) trietoxysilane for adsorption methylene blue. In The $3 \mathrm{rd}$ Annual Applied Science and Engineering Conference (AASEC), edited by Rachid, B., Cherifa, B.Z., Vladimir, B., Heidi, G., Eric, L., Ming-Jung, Z. \& Zhein, Z. Bandung, Indonesia: MATEC Web of Conferences, April 11, 2018. 197: 09009

Zhang, F., Shen, G., Ji, S. \& Yang, B. 2015. Recent advances of stationary phases for hydrophilic interaction liquid chromatography and ion chromatography. Journal of Liquid Chromatography and Related Technologies 38: 349-352.

Zhang, X., Wu, W., Wang, J. \& Tian, X. 2008. Direct synthesis and characterization of highly ordered functional mesoporous silica thin films with high amino-groups content. Applied Surface Science 254: 2893-2899.

Roza Linda* \& Abdullah

Department of Chemistry Education

Faculty of Education and Teacher Training

University of Riau, Pekanbaru

Indonesia

Mohamad Rafi

Department of Chemistry

Faculty of Mathematics and Natural Sciences

IPB University, Bogor

Indonesia 
Aster Rahayu

Department of Chemical Engineering

Faculty of Industrial Technology

Ahmad Dahlan University, Yogyakarta

Indonesia

Lee Wah Lim \& Toyohide Takeuchi

Department of Chemistry and Biomolecular Science

Faculty of Engineering

Gifu University, Gifu

Japan
*Corresponding author; email: rozalinda@gmail.com

Received: 21 April 2020

Accepted: 15 March 2021 